The International Journal Of Engineering And Science (IJES)

|| Volume || 5 || Issue || 11 || Pages || PP 08-15 || 2016 ||

ISSN (e): $2319-1813 \operatorname{ISSN}$ (p): $2319-1805$

THE IJES

\title{
The Moderating Effects of Entrepreneurial Learning on the Relationship between Entrepreneurship Orientation and Business Performance
}

\author{
Nur Asizah ${ }^{1}$, La Ode Muh. Harafah ${ }^{2}$, Nurwati $^{3}$, Baheri $^{4}$ \\ ${ }^{1}$ Doctoral Program of Economics Science, Halu Oleo University Kendari \\ Southeast Sulawesi, Indonesia \\ ${ }^{2,3,4}$ Halu Oleo University Kendari. Southeast Sulawesi, Indonesia
}

ABSTRACT-

The purpose of this study to know the Influence of Entrepreneurship Orientation on Business Performance with Entrepreneurial Learning as Moderating Variable in Small Medium Enterprises (SMEs) in Southeast Sulawesi (Studies in the Food Industry). Population totaled 109 IKM foods that have met the criteria spread over 4 (four) districts in Southeast Sulawesi province, that consists of: Konsel, Bombana, Kolaka and Kendari. The analysis technique used is Structural Equation Modeling (SEM) of AMOS7 and statistical software package SPSS (Statistic Packages for Social Sciences). In this study, researchers tested the validity of the simple correlation technique with SPSS version 12.0 The results of this study showed that the entrepreneurial orientation plays an important role in improving the performance of SMEs. The next entrepreneurial learning plays an important role in improving the performance of SMEs. There is a direct influence on the business performance of learning entrepreneurial SME food but not significant. The results of this study also prove that the entrepreneurial orientation moderated by entrepreneurial learning plays an important role in improving the performance of SMEs. This means that the entrepreneurial orientation will be stronger and not directly served to increase the performance of SMEs when supported with the right entrepreneurial learning in improving the performance of SMEs. This means that we need a learning that is applied so that the benefits of learning to give importance in the improvement of the performance of SMEs.

Keywords: SME, Enterprise Orientation, performance, entrepreneurial learning

$\longrightarrow$ Date of Accepted: 22 November 2016

\section{INTRODUCTION}

Indonesia as a country that has a population of 230 million is still very minimal own entrepreneurs. Based on the data, only about $0.18 \%$ of the Indonesian population of the total population was entrepreneurs. Though the consensus, a country in order to advance, the entrepreneur must have a minimum of at least $2 \%$ of the total population. Opportunities for growth entrepreneurs in this country are actually quite large, but strangely unemployment from time to time actually increased. One major contributor to unemployment and continued to increase over time are those with the status of scholars.

The manufacturing sector is a major component in the development of national economy, because the sector is not only the potential to provide a large economic contribution through value added, employment and foreign exchange, but also able to provide a major contribution in the transformation of cultural nation toward modernization of a society that supports the establishment of national competitiveness. Industrialization in Indonesia since the first light until today has achieved the expected results. At least, the industry has resulted in the transformation of the structure in Indonesia.

Although it has an important role in the economy in Indonesia, many aspects are still the constraints faced by SMEs (Kuncoro, 2008) include: access to capital, access to technology and information, market access and marketing, access to the professionalism of human resources, as well as access to the company's management, The cause of these obstacles, allegedly due to weakness of character, entrepreneurial, and yet Pharmaceutics managerial role in managing the business in a changing environment. In general, the main problems faced by SMEs in Indonesia are a productivity problem. With a total population of labor and SME business units are large (about 99\%) was only able to contribute less than $60 \%$ of the total output of the national effort. On the other side of the large-scale enterprises with a population of about $1 \%$ of the total national effort control almost half of the national output. This reflects that there is inequality between the productivity of SMEs with large-scale enterprises (Irawan, 2007). 
SMEs in Southeast Sulawesi have problems that are not much different from the problems of SMEs at the national level. Viewed from the aspect of education, most of the advanced education only (34.2\%), and only $6 \%$ who had received higher education. From the aspect of marketing, is still limited to the local market. In addition SMEs also still largely utilize simple technology or traditional (Bank Indonesia Kendari Branch, 2008) In line direction of national development in Southeast sector manufacturing industry is also an important sector, given the enormous potential in the industrial sector as an object field of business and field work and no less important as a contributor to GDP growth in Southeast Sulawesi value added. Industries corporate covered in the survey are large and medium industrial enterprises, which have a workforce of 20 people or more, including the new industrial company started its commercial operations in 2012.

Research Gede (2011), this study examines the impact of entrepreneurial orientation culture THK value (indicator Innovasi, proactiveness and risk taking) and market orientation at HPI silver in Bali. This study proves that aspect pawongan (harmonization of human relationships) is an important aspect in the local culture THK, innovative attitude is an important aspect in the entrepreneurial orientation, further knowledge of the market is an important aspect in the implementation of market orientation. Thus, this research has proved that the values of local culture THK make an important contribution in influencing the ability of entrepreneurial orientation and market orientation.

Entrepreneurship orientation to performance as Djamerang Asdar Research (2012), that the entrepreneurial orientation does not significantly influence the performance improvement industry. However, the more effective the role of entrepreneurial orientation was able to improve the performance of the company if it has a good strategic planning. Lee and Tsang (2001, p 593) showed positive results 'internal locos of control', the variable 'need for achievement' 'self-reliance' is not significant. Steward et al. (2003 p 39) showed a negative influence on the entrepreneurial orientation towards goal orientation. Sangen (2005) also showed negative influence (significant at the $10 \%$ level) of the variable 'entrepreneurial orientation' to 'performance'. Research reswanda; (2011) using (1) innovative (2) proactive and (3) risk taking), also showed negative results. Where the business scale of MSMEs still dominated by micro-scale enterprises, employment patterns relative does not have a vision and a business plan that is less clear and still oriented towards operational from day to day (day-today operational oriented). The impact is insignificant to the performance of the business, the business performance is actually the result of the impact of planning and implementing business plans mature.

According to Wiwihartati Badawi (2011), that the entrepreneurial orientation can enhance the willingness on learning orientation, market orientation can improve learning orientation; learning orientation can improve the ability to innovate. Learning orientation can strengthen the entrepreneurial between orientation relations to the ability to innovate. The ability to innovate can improve the relationship between orientation entrepreneurship against business performance. The study above also synergies with some studies such as research Muzakar Isa (2011), that producers need to pay attention because it affects aspects of entrepreneurship orientation has positive and significant impact on performance, as well as entrepreneurial competence owned businesses. In line with Reswanda (2011), that the entrepreneurial orientation is important in improving organization learning. Lee (1997) found that higher education institutions are very important and strategic role for the improvement of the intentions for women entrepreneurs.

Research Lee D. Y And EWK Tsang (2001), results from this study indicate that: experience, network activity, number of partners, locus of control and the need for Achievement positively related to the growth of the business, other personality traits, self-reliance and extroversion are associated negatively on the number of partners and positively related to network activity, education on business growth moderated by firm size are positively related to large companies and negatively affect small companies and entrepreneurial Industry selanjudnya managerial experience is a dominant factor influencing the growth of the business.

Research on the effect of learning orientation on performance has also been conducted. As Sutanto J.E Research (2009), that there Effect of learning orientation has a significant influence on the performance of individual members of the Business organization. Knowledge must be obtained and shared among members of the organization. The success of organizational learning occurs when individuals shared learning through positive dialogue and transformation to another individual with the support of the institution.

Noting the findings above, it wants to be examined the " The influence Entrepreneurship Orientation on performance of Small and Medium Industries: Entrepreneurial Education as Moderation (Study in the food industry in Southeast Sulawesi)?

\subsection{Definition of Entrepreneurship Orientation}

\section{LITERATURE REVIEW}

The literature describes the orientation of entrepreneurship as an "entrepreneur personlity" (Littunen, 2000, Lee and Tsang, 2001; Olson, 2000, p 2). On the other hand Hisrich, Petes, and Shepherd, 2005, 62) declared as an entrepreneurial feelings'. Orientation or personality or feeling include: a. Entrepreneur's Achievement motivation (EAM) Littunen, 2000, Lee and Tsang, 2001) which includes: 
a) Work ethical

b) Pursuit of excellence

c) Mastery in Business

d) Dominance (leader)

b. Locus of control (Littunen, 2000, Lee and Tsang, 2001; Olson, 2000: 5)

a) By chance

b) By internal

c) By external

c. Self-Reliance (Lee and tsang 2001)

d. Extroversion (Littunen, 2000, Lee and Tsang, 2001)

e. Innovating (Lumpkin, 1996: 151; Vitale, Giglierano and Miles, 2003: 5)

f. Acting proactively (proactiveness) (Lumpkin, 1996: 151; Vitale, Giglierano and Miles, 2003: 5)

g. Managing Risks (Risk Taking) (Lumpkin, 1996: 151; Olson, 2000: 5); Vitale, Giglierano and Miles, 2003: 5)

h. Ambition (Olson, 2000: 5)

The above definition is consistent with the notion of the entrepreneur's profile in the 1980s (see K., 1999) such as, among others:

a. Confident (Self-confidence)

b. Oriented to the task (Task-result oriented)

c. Dare to take risks (Risk taker) (loss include: time, money, health and life)

d. Have an attitude of leadership (Leadership)

e. Have authenticity (Originality)

f. Oriented future (Future-oriented) (Results Workshop entrepreneurship East-west Centre Honululu 1977; Meredith, Nelson and Neck, 1982; Bursch 1986; Patel, 1987). Or other characteristics, namely:

a. Proactive - 'initiated' before asked / forced by circumstances and being 'assertiveness" i.e. as soon as possible to solve the problem and stating how to solve them on others.

b. Achievement - namely being able to see and promptly act upon opportunities, work efficiently, have attention to the quality, plan systematically, always monitor whether the work in accordance with the standard; and

c. Commitment - which remove 'extraordinary effort' to complete a job, as well as 'Recognize' (recognize) the importance of customer relationships / customers (Scarborough and Zimmerer, 1993; K., 1999).

Subsequently explained also the aggregate measurement of entrepreneurial orientation is based on the assumption that these three dimensions the same contribution to the overall level of entrepreneurial orientation of the company in all situations Covin and Slevin, 1989). But the development of literature states that each Dimension can provide a unique contribution to the entrepreneurial nature of the company (Lumpkin and Dess, 1996) is possible if the third dimension of orientation These entrepreneurs will have a different relationship with important variables such as the company's performance. But few studies that examine the contribution of the three dimensions of entrepreneurial orientation on firm performance (Lumpkin and Dess, 2001).

Three Dimensions of Entrepreneurial Orientation, namely:

a. The tendency of companies to innovate (innovativeness)

b. The tendency of companies to take risks (risktaking).

c. Company to Acting Proactive tendency (proactiveness).

From the above explained in the study of entrepreneurial orientation is a characteristic taken from the indicator instrument (Lumpkin, 1996; Olson, 2000); Vitale, Giglieranoand, Miles, 2003), and Orientation Entrepreneurship with indicators by adopting research Asdar Djamerang, (2012)

\subsection{Entrepreneurial Learning}

Kolb (1984) states that learning is experiential, is a process by which the concept is obtained continuously and modification. A process emerges through successful experiences, not knowledge of the future ". Deakins and Freel (1998) revealed that the relevant entrepreneurial learning theories, including the theory of organizational learning, evolutionary theory and dynamic as well as the impact of a small company network on entrepreneurial learning. Each theory will be described as follows:

Organizational learning theory assumes that individuals relate to each other in an institution or a model of the learning process can be useful to capture the dynamics of individual learning (Deakins and Freel, 1998). This model is often irrelevant in entrepreneurial small companies. Entrepreneurial must react and change behavior as a result of interactions with an infrastructure of competitors, customers and resource providers. The concept of community learning stated by Hendry (1996) about a useful approach to the individual interaction and learning process in a large organization are not necessarily relevant to entrepreneurial learning in small firms. 
In connection with the key issues in the process of learning and entrepreneurial development, Hall (1996) raised the key issues relating to learning through education and training (education and training), coaching (mentoring), and experience (experience). The understandings of each issue are as follows:

1) Learning through Education and Training

Ranupandojo and Husnan (2002) suggested the term education and training are often used interchangeably with the term development. In practice, both terms have the same purpose:

(1) Education is an activity to improve a person's general knowledge including increasing mastery of the theory and skills of taking decisions on issues concerning the activities to achieve goals.

(2) Exercise is an activity to improve a person's ability to work in relation to economic activity. Training helps employees understand a practical knowledge and its application to improve skills, skills, and attitudes needed by the organization in order to achieve objectives.

\section{2) Learning through Mentoring}

Brown (1990) reveals, in context of the entrepreneurial mentoring is a process of learning from the experience of someone who can help an entrepreneur towards the formation of new knowledge. Mentoring has a relationship with a person's ability and the secret of success of the company. Mentoring is suitable to support a new entrepreneur which is a way of learning to develop the skills of potential. Research on mentoring was conducted by Kathy (1983) identified two general functions of mentoring, which is a function of career and psychosocial functions.

\section{3) Learning through Experience}

Robinson and Sexton (1994) suggested that learning from experience is an integrated process with a job in the real business practice. Approach to learning from this experience provides the ability for individuals and organizations to perform self renewal to conduct a proactive approach and self-learning development in a long-term career. Experiential learning approach is very useful for the development of an entrepreneur, because this learning can provide opportunities for entrepreneurs to take advantage of on-the-job experience and provide Meta skill for learning how to learn.

Entrepreneurial Learning in the study of the opinion adopted from Hall (1996) raised the key issues relating to learning through education and training (education and training), coaching (mentoring), and experience (experience) which is measured by three indicators (Sanjoyo, 2004) and item indicators adopted from the research I Gede Riana, (2011) include education and training (education and training), coaching (mentoring), and experience (experience).

\subsection{Business Performance}

Literally business performance can be defined as something that is achieved, demonstrated achievement and employability. In general the performance expected by the company is in the form of performance achieved by the company within a certain period. Work performance to be achieved Companies generally linked to the aims to be achieved by the firm. Businesses Organization generally can measure the performance of its business using financial measures (sales growth, profit growth and asset growth) or nonfinancial (employee turnover, customer satisfaction, and productivity).

According Covin and Slevin (1989) procedure performance measurement Small and Medium Industries to do with the assessment of respondents' perception is based on the Likert scale on several financial measures such as: the level of sales, sales growth, gross profit, the ratio of gains on sales, return on equity, and net income operation. Thus the measurement of business performance will greatly depend on how valid these measures in accordance with the performance achieved by the Small and Medium Industries. This study uses three indicators to measure the performance of small businesses Medium Industries (SMI), namely: sales growth, profit growth and asset growth.

From the explanation of some of the performance indicators in this study measure business performance refers to research conducted by Lee and Tsang (2001), and the Holy rahayu (2008), I Gede Riana (2011) by using three indicators include: sales growth, profit growth, and asset growth.

The conceptual framework is structured to explain the variables which serve as an exogenous variable, the moderating variable and endogenous variables. With prepositions is based on theoretical and empirical studies will be known how many hypotheses to be drawn up, the variables contained in each of these hypotheses, and how the influence of the relationship between the variables. Based on these descriptions, the conceptual framework of research that showed the relationship between variables as illustrated in Figure 1.1. 


\section{CONCEPTUAL FRAMEWORK AND HYPOTHESIS}

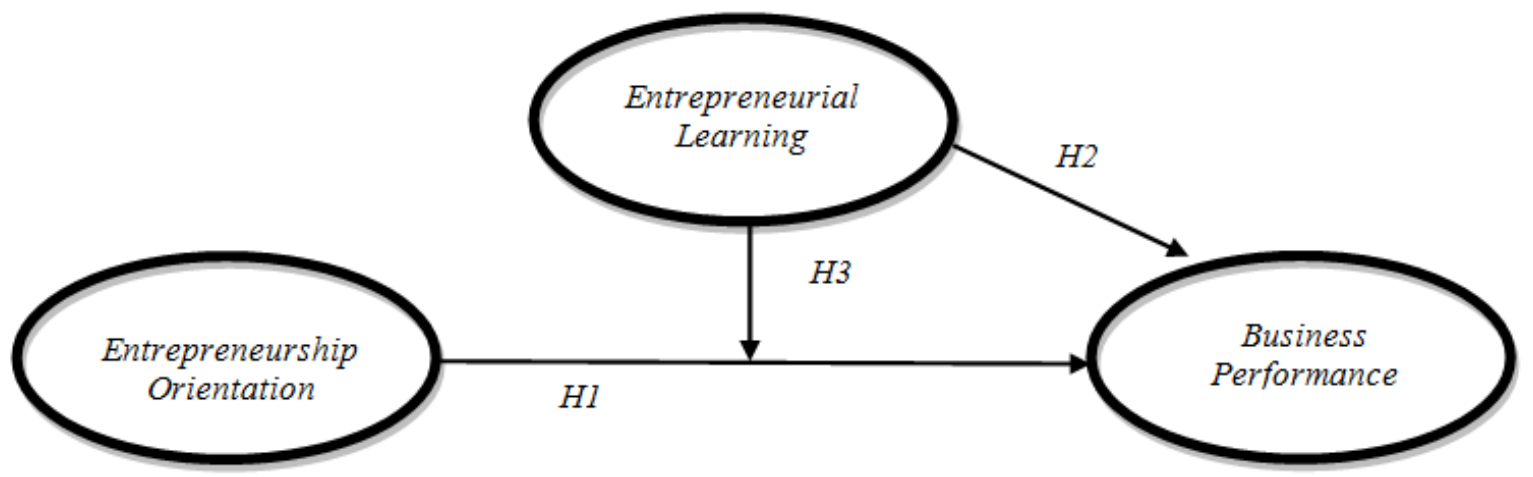

Hypothesis:

H1. Orientation entrepreneurial has significant effect on business performance in the SME food in Southeast Sulawesi province.

H2. Entrepreneurial Learning has significant effect on business performance in the SME food in Southeast Sulawesi province.

H3. Entrepreneurship Orientation has significant effect on business performance by Entrepreneurial Learning as a moderating variable in the SME food in Southeast Sulawesi province.

\subsection{Population}

\section{METHODOLOGY}

The population in this study based on the amount of labor used in the 5-99 criteria so totaled population are 109 IKM foods that have met the criteria spread over 4 (four) districts in Southeast Sulawesi province, that consists of: Konsel, Bombana, Kolaka, and Kendari.

\subsection{Research Instruments}

Data were collected using a questionnaire consisting of questions about the characteristics of respondents and questions about the variables studied. Questions are presented in the form of open-ended questions and statements, and scale to express the response. A statement in the list of questions pertaining to the assessment of the influence of the leader or entrepreneur entrepreneurial orientation and entrepreneurial learning as moderating variables on the performance of SME food businesses in Southeast Sulawesi province.

\subsection{Data Analysis Techniques}

The analysis technique used is Structural Equation Modeling (SEM) of AMOS7 and statistical software package SPSS (Statistic Packages for Social Sciences) In this study, researchers tested the validity of the simple correlation technique with SPSS version 12.0

\subsection{Analysis SEM}

\section{RESULT AND DISCUSSION}

The test results with structural equation model (Structural Equation Modeling) with AMOS 16 can be seen in Table 1. This table showed that the model is feasible used for proving the hypothesis.

Table 4.1 Testing Goodness of Fit Model Overall

\begin{tabular}{|l|c|c|c|c|}
\hline \hline \multicolumn{1}{|c|}{ Goodness of Fit } & \multicolumn{2}{|c|}{ Account Result } & Good Requairement & Description \\
\hline & Result & Meaning & & Gmall \\
\hline Chi Square & 1,642 & Small & & Good \\
\hline Probability & 0,200 & $>0,05$ & $>0,05$ & Good \\
\hline CMIN/DF & 1,642 & $\leq 2$ & $\leq 2$ & Good \\
\hline GFI & 0,990 & $\geq 0,90$ & $\geq 0,90$ & Good \\
\hline AGFI & 0,940 & $\geq 0,90$ & $\geq 0,90$ & Good \\
\hline TLI & 0,984 & $\geq 0,90$ & $\geq 0,90$ & Good \\
\hline CFI & 0,995 & $\geq 0,90$ & $\geq 0,90$ & Good \\
\hline RMSEA & 0,077 & $\leq 0,08$ & $\leq 0,08$ & Sod \\
\hline
\end{tabular}

Source: Primary data 


\subsection{Test Results Analysis Effect}

Based on the analysis of SEM, causal relationships between variables can then test the hypothesis described in Table 2 as follows:

Table 4.2 Table test results Effect of entrepreneurial orientation on business performance by Entrepreneurial Learning as a moderating variable

\begin{tabular}{|l|c|c|c|c|c|c|}
\hline \hline \multicolumn{1}{|c|}{$\begin{array}{c}\text { Independent } \\
\text { Variable }\end{array}$} & $\begin{array}{c}\text { Moderating } \\
\text { Variable }\end{array}$ & Dependent Variable & $\begin{array}{c}\text { Path } \\
\text { Coeffisient }\end{array}$ & CR & P- Value & Description \\
\hline $\begin{array}{l}\text { Entrepreneurship } \\
\text { Orientation }\end{array}$ & & $\begin{array}{c}\text { Business } \\
\text { Performance }\end{array}$ & 0,222 & 0,899 & 0,035 & Significant \\
\hline $\begin{array}{l}\text { Entrepreneurial } \\
\text { Learning }\end{array}$ & $\begin{array}{c}\text { Business } \\
\text { Performance }\end{array}$ & 0,209 & 0,938 & 0,051 & Not Significant \\
\hline $\begin{array}{l}\text { Entrepreneurship } \\
\text { Orientation - }\end{array}$ & $\begin{array}{l}\text { Entrepreneurial } \\
\text { Learning }\end{array}$ & 0,312 & 0,947 & 0,000 & Significant \\
\hline
\end{tabular}

Source: Primary data

\subsection{Discussion}

\section{Effect of entrepreneurial orientation on business performance}

The results of the study showed that entrepreneurial orientation has direct influence business performance values obtained significant positive path coefficients (Table 5:15). With the path coefficient is positive, meaning there is a unidirectional relationship between entrepreneurial orientation with business performance. The higher the entrepreneurial orientation in the SME (the food industry) in Southeast Sulawesi it will lead to increased business performance.

Based on the results of descriptive statistical analysis, entrepreneurial orientation is perceived both by the entrepreneurs it's just the perception of entrepreneurs to the indicator of innovation is still lacking (Table 5.9). Similarly, his thing with the perception of entrepreneurs towards proactive indicator, even though the average (mean) perception of entrepreneurs towards better risk indicator. Therefore, entrepreneurs are expected to be more proactive in order to beat competitors from entering the market, increasing the quality and number of features of the product before competitors do and fostering partnerships with the best partner before competitors.

Based on the analysis of descriptive statement of the entrepreneur (the food industry) perceive that the business performance of SMEs (the food industry) poor (being). This is evident from the description of an entrepreneurial response to sales growth, profit growth, asset growth and perceived still lacking (being) either by the entrepreneurs. Empirically dominant indicator contributes to business performance is the growth in profits. With the growth in profit would theoretically be able to improve asset.

\section{Effect of entrepreneurial learning on business performance}

The results of the analysis of entrepreneurial learning directly influence on business performance of food SMEs with values obtained positive path coefficients and insignificant. This indicates that learning entrepreneurial influence on business performance. Path coefficient is positive and not significant mean there is a unidirectional relationship; though not provide the sense of learning orientation entrepreneurs with business performance. The stronger the entrepreneurial learning will improve the performance of the SME food in Southeast Sulawesi province.

From the results of the descriptive analysis of entrepreneurial learning is perceived well by the SME food. The highest average score on this indicator means that the SME food experience perceive that in carrying out the task or work always pays attention to previous business experience, business continuity to learn from experience and critical incident that experienced breathing should be noticed and constantly learn from past experience. This will result in increased performance.

Based on the test results prove that the dominant indicator of contributing to the performance is the experience and guidance. Thus it can be interpreted that SMEs that work with the guidance provided with a good mentor and remember the experience of business will have an impact on the quality of work better that SMEs can further increase the volume of sales, profits also increased and business assets also increased.

\section{Effect of entrepreneurial orientation on business performance by Entrepreneurial learning as a moderating variable}

The analysis results directly Orientation Entrepreneurship against previous working coefficient values obtained significant positive path. This shows that the entrepreneurial orientation influence performance. Path coefficient is positive, meaning there is a unidirectional relationship between entrepreneurial orientations on performance. The stronger the entrepreneurial orientation will improve business performance in the SME food of Southeast Sulawesi province. 
Furthermore, from the analysis results on the performance orientation Entrepreneurship with entrepreneurial learning moderation coefficient values obtained significant positive path. Based on the test results prove that the dominant indicator contributes to entrepreneurial orientation on performance are moderated by the entrepreneur is learning the risks and experience. Thus it can be interpreted that the SME food that works with the courage to take risks and pay attention to a variety of business experience had then been shown to promote the growth of profits IKM food in Southeast Sulawesi province, namely SMEs to work more proactively, taking risks in business, and think about the possibilities of innovation can improve business performance.

\section{CONCLUSION}

Entrepreneurial orientation was measured using three indicators, namely innovation, proactive and risktaking that high can improve the performance of SMEs shows that proactive and courage to take risks is the strongest indicator as a measure of entrepreneurial orientation. While Innovation still not as good as finding new target market, the creation of new products, and channel distribution. Strengthening the role of entrepreneurial orientation through a proactive attitude and courage to take risks reflecting that food SMEs in Southeast Sulawesi in executing its business constantly need to introduce new products before competitors do, in an effort to increase the value for customers' need, need to foster good relationships with customers, it is important implement technological processes to be more efficient than its competitors and is crucial to improve the quality before competitors do this risk has been done by the SMEs are good at running a business there is always a way transform and avoid failure, to make changes at least reduce the risk, the risk of losing the opportunity as important as the risk failure.

Entrepreneurial having high entrepreneurial learning to be aware of the importance of education and the importance of training, coaching and the importance of learning from good experiences will be able to make better business performance. Reflected natural result of guidance and learn from experience

The results of Guidance and learn from experience that in running the business have the confidence, requires the role of supervising and coaching advice from the results is needed. In addition there is a critical incident in running the business always learns from experience. This finding could be explained that the guidance and experience should be the primary concern in carrying out the work. In addition, entrepreneurs are expected to continue to hone the skills or capabilities through education and training is still lacking.

Entrepreneurs who have good performance shown by the increase in sales volume, increased operating profits and assets of the company increased from year to year increases the performance of the business

The sales growth is the strongest indicator to measure entrepreneurial learning. Instead description indicates that the perception of the development of SME food gain a dominant factor in measuring the performance of entrepreneurs. From this finding can be explained that sales growth should be the primary concern in carrying out the work. In addition, the expected profit is also constantly evolving so that the company can still survive in business. The influence of Entrepreneurship orientation on business performance moderated by entrepreneurial learning as reflected in the Entrepreneurial having high entrepreneurial learning will have an awareness of the importance of mentoring and the importance of learning from experience increasingly evident strengthen business performance.

\section{SUGGESTION}

Based in the study results and discussion, it is suggested that:

1. The next study will use a longitudinal design to examine the causal variable entrepreneurial orientation, entrepreneurial learning and its impact on SME performance

2. In order to give a generalization of environmental influences industrial, entrepreneurial orientation on performance with an entrepreneurial learning as a moderating variable in the SME food should be held in addition to continued research on food IKM also other food industries in other regions

3. Indicators of entrepreneurial orientation measurements used in this study only included innovativeness, risk taking, proactiveness for further research is recommended to use or add to other indicators, such as selfconfidence, Task-result oriented, Leadership, Internal locus of Control as indicator of variable entrepreneurship orientation

4. For further research, this study can be used as reference for subsequent theoretical and empirical study on the factors that affect the business performance of SMEs by linking with a variable outside This study model that determines the success of the business performance of SMEs as other factors both variables government policy, culture and other variables that have not been used in this study. 


\section{REFERENCES}

[1]. Alma, Buchari, (2007) Kewirausahaan, pertumbuhan jiwa wirausaha bagi mahasiswa dan masyarakat. alfabeta Bandung

[2]. Dinas perindustrian dan perdaganagn provinsi Sulawesi Tenggara, Data sentra Industri Kecil provinsi Sulawesi Tenggara Tahun 2013. Dinas perindag. provinsi Sultra.

[3]. Fitri Lukiastusti, (2011) Pengaruh Orientasi Wirausaha Dan Kapabilitas Jejaring Usaha Terhadap Peningkatan Kinerja Ukm Dengan Komitmen Perilaku Sebagai Variabel Interviening Studi Empiris Pada Sentra Ukm Batik Di Sragen, Jawa Tengah) Jurnal Organisasi dan manajemen vol.1, No. 1 januari 2012, hal 29-37

[4]. Huber, G.P., 1991. Organizational Learning: The Contributing Processes and The Literatures. Organization Science, Vol.2 No.1, February, pp. 88-115.

[5]. http://infoukm.wordpress.com/2008/08/11/keragaman-definisi-UKM-di- Indonesia/

[6]. I Gede Riana, (2011) Dampak penerapan nilai kultur THK terhadap orientasi kewirausahaan dan orientasi pasar pada IKM kerajinan perak di Bali.Jurnal Teknik Industri, Vol. 13, No. 1, Juni 2011, 37-44 ISSN 1411-2485 print / ISSN 2087-7439 online

[7]. Lumpkin, G.T.\& Dess, G.G. (1996). 'Clarifying the Entrepreneurial Orientation Construct and Linking It to Performance', The Academy of Management Review, Vol.21 No.1 p.135-172.

[8]. Khandekar, A and Sharma, A, 2006. Organizational learning and performance : Understanding Indian Scenario in Present Global Context. Journal Education and Traning, 48 (8-9):682-690.

[9]. Kuncoro. M. (2008). Bisnis Indonesia, 21 Oktober 2008

[10]. Kohli, A. K., \& Jaworski, B. J., 1990. Market Orientation: The Construct, Research Propositions and Managerial Implications. Journal of Marketing, 54 (April), 1-18.

[11]. Kotler, Philip, 1994. Manajemen Pemasaran: Analisis, Perencanaan, Implementasi dan Pengendalian, Jakarta: Salemba Empat.

[12]. Kuratko D. F. dan Hodgetts, R. M. (1992). Enterpreneurship : A Conteporary Approach. Permissions, Holt, Rinehart and Winston Inc. Florida.

[13]. Lumpkin, G. T. dan Dess, G. G. (2001). Linking two dimensions of entrepreneurial orientation to firm performance: The moderating role of environment and industry life cycle, Journal of Business Venturing, 16(5), pp. 429-451.

[14]. Lumpkin G..T and G.regory G.. Dess, 1996. Clarifying the Entrepreneurial Orientation Construct and Linking It to Performance. Academy of Management Review, Vol. 21(1), pp. 135-172

[15]. Lee, D.Y., dan Tsang,E.W.K. (2001). The Effects of Entreprenurial Personality Backround and Net work Activities on Venture Growth. Journal of Management Studies. Vol. 5(3) pp 83-109.

[16]. Mahmud, Ariati Anomsari, (2011) Analisis Pengaruh Orientasi Kewirausahaan, Kemampuan Manajemen, Dan Strategi Bisnis Dalam Peningkatan Kinerja Perusahaan (Studi Pada Usaha Kecil Menengah Di Kawasan Usaha Barito Semarang) Seminar nasional teknologi dan komunikasi Terapan 2011; ISBN 979-26-1255-0

[17]. Matsuno K., John T. Mentzer and Aysegul Ozsomer, 2002. The Effects of Entrepreneurial Proclivity and Market Orientation on Business Performance. Journal of Marketing, Vol. 66 No. 3; pp. 18-32.

[18]. Miller, D. (1983). The Correlates of Entreprenuership in Three Types of Firms. Management Science, $29,770-791$.

[19]. Miller, D., 1988. Relating Porter's Business Strategies to Environment: An Empirical Examination with American Data, Organization Studies, Vol.7.

[20]. Mills, D.Q. and B. Friesen, 1992. The Learning Organization. European Management Journal, Vol.10 No.2 June, pp. 146-156.

[21]. Muryati, 2004, Intensitas Strategi Bersaing dan Kinerja Ekspor pada Industri Kecil produk Kerajinan Kayu di Propinsi Jawa Timur, Disertasi tidak dipublikasikan, PPSUB., Malang

[22]. Muzakar Isa, (2011) Analisis Kompetensi Kewirausahaan, Orientasi Kewirausahaan, Dan Kinerja Industri Mebel (BENEFIT Jurnal Manajemen dan BisnisVolume 15, Nomor 2, Desember 2011, hlm. 159-168

[23]. Naman, John L and Dennis P. Slevin, 1993. Entrepreneurship and The Concept of Fit : A Model and Empirical Tests. Strategic Management Journal. Vol. 14 No. 2, pp. 137-153

[24]. Naver, J.C. and Slater S.F., 1990. The Effect of Market Orientation On Business Profitability, Journal of Marketing, 54 (October), pp 20-25

[25]. Nurhayati (2004), analisis factor-faktor yang mempengaruhi kinerja dan keunggulan bersaing usaha kecil yang berorientasi ekspor di jawa timur, Disertasi yang tidak di terbitkan, PPSUB, Malang

[26]. Porter, M.E., 1998. Competitive Advantage, Creating and Sustaining Superior Performance, With a New Introduction, New York: The Free Press.

[27]. Rahab Dan Sujdono, (2011) Pengembangan Kapabilitas Keinovasian Ikm Berbasis Pada Orientasi Kewirausahaan Dan Pembelajaran Organisasional Jurnal Inovasi Dan Kewirausahaan Vol.1, Nomor 1 Januari 2012, Hal 29-37

[28]. Reswanda, (2011) Pengaruh Orientasi Kewirausahaan terhadap Pembelajaran Organisasi,Keunggulan Daya Saing Berkelanjutan dan Kinerja Usaha pada UMKM Kerajinan Kulit Berorientasi Ekspor di Sidoarjo ..Jurnal Diserta- Universitas Air Langga maret 2011 